\title{
Conceptual Analysis of Comprehensive Income and Operating Income: evidence in the Brazilian Financial Sector
}

\author{
Antônio Carlos Coelho* \\ University of São Paulo \\ Luiz Nelson Carvalho** \\ University of São Paulo
}

\begin{abstract}
The paper discusses the concepts and meaning of comprehensive income, clean surplus relation, all-inclusive income, current operating income, clean income and dirty surplus. These are discussed from a theoretical standpoint, demonstrating their conceptual divergence as well as their varied applications, either through valuation models based on company accounting figures or reported accounting income. Then examples of accounting rules and standards referring to these concepts are analyzed, showing that in the United States and United Kingdom these concepts are already reported in specific financial statements. In addition, international empirical studies on the subject are reported and applied to calculations for the Brazilian financial sector for the 2001-2004 period, in function of new regulations on appropriation of the appreciation of securities through direct recording in the equity accounts. Evidence is found that the total increment in equity was not recognized in the accounting results disclosed, and the difference was greatest in the period immediately after the regulatory change.
\end{abstract}

Keywords: comprehensive income; clean surplus; current operating income; earnings reports; asset/liability approach.

Received in 01/13/2007; revised in 03/26/2007; accept in 05/13/2007.

Corresponding authors:

* Rua Franz Schubert 156

01454-020 J. Paulistano

São Paulo - SP-Brazil

Tel.: 1130386700

acarloscoelho@terra.com.br
** Av. Prof. Luciano Gualberto 05508-900 Cidade Universitária São Paulo SP-Brazil

Tel.: 1130915820

lnelson@usp.br

Editor's note: This paper was accepted by Alexsandro Broedel Lopes. 


\section{INTRODUCTION}

The determination and disclosure of accounting income, one of the main objectives of accountancy, has undergone major changes as the conceptual discussion of this accounting/economic aggregate has evolved.

This discussion is not restricted to the concept of the result of a company's economic activity. It also takes in the definition of all the elements of equity that influence the determination of the firm's performance, along with questions related to temporal aspects and the realization of assets in determining its profits.

Differences exist in the concepts found in various countries and regulatory bodies, whether regarding application of accounting principles or resulting from different cultural patterns. These differences exist in spite of efforts in the field of corporate accountancy to converge practices in the measurement and reporting of accounting income.

Such diversity fits in the broader theoretical spectrum of financial accounting, given that the central idea of this theory is based on producing information that is useful to all the publics that make use of it, such as investors, creditors, government agencies, tax authorities, customers, suppliers and employees.

Within this scope, in the 1990s there was an extensive discussion about the ways to report companies' income, basically involving the concepts of comprehensive income and current operating income. This produced many empirical works, commented on later, regarding the relevance and association of these concepts with the capital market and with investors' decisions.

The main world entities that define accounting standards and principles, such as the International Accounting Standards Committee (IASC), the Financial Accounting Standards Board (FASB) and the United Kingdom Accounting Standards Board (ASB), have all issued recommendations, standards, statements and rules to expand the scope of the concept of income reported in the financial statements.

Also of importance here is the development of a formal model for appraising companies in which this variable depends exclusively on accounting information. One of the premises of this model is that income is ascertained in a clean surplus relation, that is, so that it includes all changes not coming from the owners, and that these be reported in the income statement (OHLSON, 1995).

In Brazil there has as yet been no normative or legal pronouncement on the subject, but because of the different treatment with which some equity items are being evaluated in specific sectors, the need for greater transparency in reporting income needs to be addressed, both in the academic and professional spheres.

The justification for this work rests on the issuance of Circulars 3068 of November 8, 2001 and 3082 of January 30, 2002 by the Brazilian Central Bank (BACEN), which established new forms of valuing financial assets in the Brazilian banking sector, with direct counterpart in the equity accounts.

Therefore, we investigate what the impact is of these rules on the difference between the amounts ascertained as net income in the income statement and the increase in equity, by the direct booking of variations in the value of securities.

Our hypothesis is that the differences are significant and have relevant effects from the standpoint of analysis of accounting numbers by users of the financial statements, including when considering the specific effect of increases and decreases in the valuation of the assets in question.

The objectives of this study are the following: 
a) To describe and quantify the effect of accounting appropriations made in direct counterpart with equity accounts in the Brazilian banking sector in function of recent changes in the valuation of equity items in the sector;

b) To analyze the consequences of this fact on the accounting displays in the period studied;

c) To review the underlying theory on measurement and recognition of accounting income, presenting the alternative concepts and ways to report accounting income;

d) To examine the framework of general legislation and the existing empirical evidence on the subject, in Brazil and internationally.

The rest of this paper is organized starting with the presentation of the mentioned theoretical framework (Chapter 2), followed by Chapter 3, which covers the methodology used, and Chapter 4, which presents the results of the study made of the Brazilian financial sector. The conclusions are in Chapter 5.

\section{THEORETICAL FRAMEWORK}

The theory of accountancy has in the past century been adapting the concept of measuring accounting income to the economic ideas about the meaning of income in the commercial activity of business enterprises.

Therefore, the eminently syntactic concern of accountancy to measure income only from the commercial transactions in a given period, by comparing the price of the transaction with the historic cost of the factors used in producing and distributing the good or service, has given way to other forms of assessment.

Interest has shifted to demonstrating all the growth in the firm's equity in a given period based on validating the value of the assets according to the market, even when not limited to a commercial event, by a valuation that has a satisfactory degree of measurement certainty, or connection with the expenses, and of realization, whether present or future.

Starting with the concept proposed by Hicks and Rubinstein (HENDRIKSEN; VAN BREDA, 1999), that a company be appraised by the value of its expected cash flows, discounted by an appropriate opportunity cost, the traditional model of appraising assets for accounting purposes by their historic cost started to be questioned. As a corollary, the historical distinction between economic income and accounting income became more important.

Solomons (1966) presents the following differences between the two concepts:

a) The values of the changes in tangible assets, not realized in the period;

b) The amounts realized in the period referring to these changes not recognized in previous periods;

c) The changes in values of intangible assets, that is, the changes in the firm's goodwill.

In this line of reasoning, taking the definition given by Hicks (1946, p. 172) that "Income is what we can consume in a week and still expect to be as well off at the end of the week as at the beginning," and adapting it, accounting theory starts to accept another formulation of income, as follows:

$$
\begin{aligned}
L_{j} & =F C_{j} \pm A C j \pm\left(P L_{j}-P L_{j}-1\right) \\
\text { onde: } & \\
L_{j} & =\text { Net income of period } \mathrm{j} ; \\
C F j & =\text { Cash flow generated in the operations in period } \mathrm{j} ; \\
A C j & =\text { Accruals in period } \mathrm{j} ; \\
N E_{j}, j-1 & =\text { Net value of assets at the end of and start of period } \mathrm{j} .
\end{aligned}
$$


Note that this model combines the ideas of gains obtained through transactions (the elements associated with cash flow and accruals) and the increases in assets/ decreases in liabilities resulting from revaluations at fair market value of the elements of equity operated and controlled by the firm.

Furthermore, with this change in perspective, accounting theory now accepts that increases in assets do not necessarily depend on their sale, but rather on a continuous process of production and distribution of goods, the vegetative growth of primary materials and price changes in financial assets.

Therefore, the recognition of revenues is not restricted to the principle of change in ownership of a good or service independent of its realization. This realization occurs by critical events that characterize the recognition by the market of the fair value of the good or service, hence assuming that equity elements are valued by the future benefits expected of them, given a certain degree of certainty of their realization.

We can list some examples of this situation, such as:

a) Long-term constructions whose revenue is appropriated during the process and not on the sale or transfer of the product;

b) Stocks of commodities and precious metals, whose values are adjusted while still in inventory to the market price, because they are always in demand;

c) Organic growth of primary goods, such as wines or cattle, where there is qualitative or physical addition to the goods, causing them to be reappraised as "new stock".

The recognition of revenues thus should be accompanied by some requisites of the following type:

a) That the transaction has added value to the product, service or good, and this value is measurable;

b) That this measurement is verifiable;

c) That it is possible to estimate the expenses (assets consumed) associated with the transaction or the increment recorded.

The evolution of these ideas has caused accounting theory to delineate two general approaches to determine income, namely the "revenue/expense" and the "asset/liability" approaches.

In the first, the recording of the changes generated by the company's activities is oriented by the transactions it carries out in a certain period. The equity positions at the start and end of the period are statistical "snapshots" of the effects of the movements that occurred in that interval.

In the other approach, the generators of the economic facts are the changes in the value of the firm's assets. Thus, any alteration in these aggregates arising directly from the firm's activity or other economic movements inside or outside it will generate a revenue or expense, and will thus cause adjustment of the firm's net worth.

The economic grounds associated with these two forms are the same, that is, the results ascertained will be identical in either of them, considering the existence of the firm.

However, the "asset/liability" view has been defended by scholars and regulators (U.S. SEC, 2003) for incorporating the economic concept of increase in the enterprise's net worth.

Also implicit in this evolution of opinions and ideas is the concept of appraising assets at their fair value, in contrast with the principle of historic cost. This means that the valuation captures, at each moment, the generation of future benefits of the enterprise's assets.

From a syntactic standpoint, the determination of accounting income, which approximates the economic conceptions of income, can be summarized in the following manner: 
a) Recognition of revenues upon selected critical events, including those involving transfer of ownership, that show the change in elements of the assets and liabilities;

b) Linkage of expenses, represented by assets consumed, with the revenues mentioned above;

c) Valuation of assets by their "fair value", adjusting gains and losses as revenue/expenses, thus becoming aggregated to equity;

d) Recognition of goodwill acquired and its successive adjustments, whether by an impairment test or some other process;

e) Adjustments due to changes in equity caused by extraordinary, non-recurring, facts, derived from changes in accounting standards or correction of past errors.

According to Solomons (1996), the use of the concept of income is linked to at least three functions: taxation, calculation of dividends and guidance for investment decisions. The focus of this study is on this third utility, because it is the reason for broad disclosure of income to the company's various stakeholders.

Taxation and dividends are only of interest to restricted publics (the tax authority and stockholders) and depend on very specific rules.

From a pragmatic standpoint, the use of accounting income will be differentiated according to the objective of the respective users. Through it one can:

a) Evaluate the firm's performance in unitary periods and over time;

b) Analyze management's performance;

c) Project/estimate future cash flows;

d) Examine the behavior and its variability or persistence, to delimit levels of uncertainty and future risk factors, and (not exhaustively);

e) Confirm policies and projections made by the company.

Moreover, in determining the accounting income in the way described in the preceding section, diverse forms and contents will be involved, which can deviate from the pragmatic sense if not organized in the required form, so as to be intelligible to specialist and nonspecialist users alike.

From the definitions presented in Robinson (1991), Johnson et al. (1995) and Keating (1999), the diagram in Figure 1 shows all the elements and concepts associated with the interpretation of accounting income to be reported.

On the second level on the left is "current operating income", which according to Hendriksen and Van Breda (1999), focuses on measuring the company's efficiency, in the sense of effective use of the resources under the control of its management. Hence, the concept is associated with the organization's recurring operations during the period under consideration. Even if there are changes in performance, these will result from normal aspects of the firm's activities. So, this level of income also indicates the performance of the company's normal operations. This must be able to explain the causes of variations and achievement of targets or not.

After adding amounts referring to extraordinary items to the current operating income, one obtains a picture of the total income produced in the period: "current income". Extraordinary items are defined generally as changes in equity resulting from irregular and uncommon events, that is, they may be operational, as long as not recurring, or nonoperational, albeit frequent. (JOHNSON et al., 1995)

The theory dedicates special attention to the accrued effects of changes in accounting principles and standards, so that the effects on the firm's equity produced by those changes should be reflected in measuring its income, by considering the accumulated effect in the periods when the changed principle was in effect. 
For this case, accountants and regulators should exercise common sense and objectivity, so as not to continually change these principles, and make sure that the period considered be relevant.

The concept of "net income", then, is associated with the ongoing functioning of the firm, because it covers the changes in its net assets resulting from its activity - normal, recurring, operational, non-recurring, non-operational - defined by intentional actions of internal agents, whether part of management or independent of it, up to that moment in the firm's life.

Two other types of events can also cause changes in a firm's net assets and should be measured after net income. The first is adjustments for errors in past periods (besides fraud). These should be fortuitous and of small importance in the context of the organization, and for this reason should be recognized after the net income, which represents the result of the enterprise's conscious efforts.

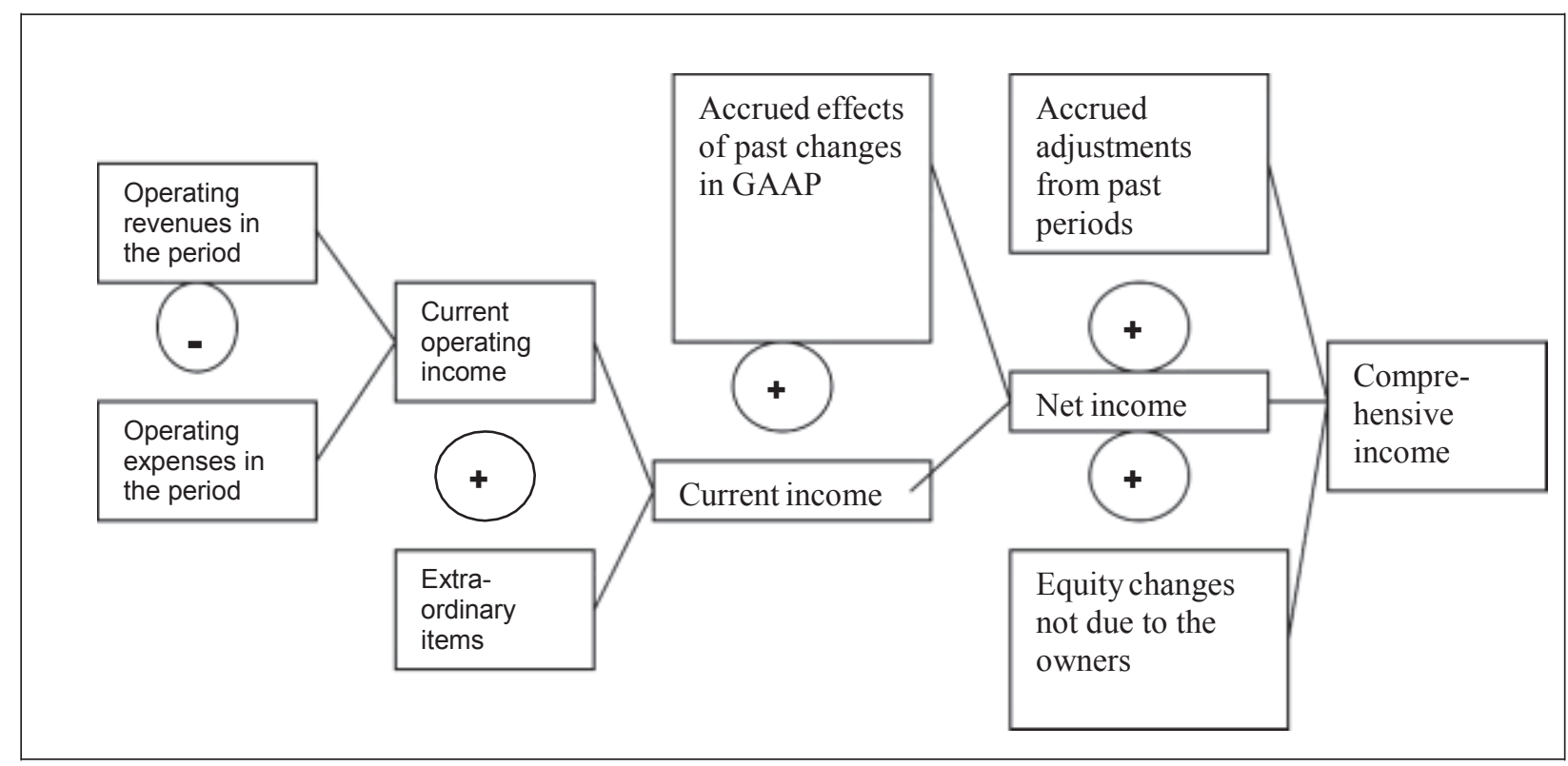

Figure 1 - Levels of Measuring Accounting Income

In cases of proven fraud or relevant adjustments, this type of event can require restatement of the financial figures, to give transparency to the facts not properly reported.

The second type of event, of extreme relevance in the context of economic valuation of the enterprise, regards the gains and losses of an ongoing or fortuitous nature that have not yet been realized in the current period, but whose uncertainty of occurrence is minimal and calculable, that is, equity variations not resulting from the owners.

Currently by far the majority view in accounting theory is that such probable changes in equity, if measurable and verifiable through the concept of fair value, should be recognized in the equity accounts.

This is the case of revaluation of assets, results of exchange rate variations, changes in the market value of financial assets, alterations in future obligations to pension funds, among others of lesser importance.

These events, resulting from the macroeconomic situation, have an impact on the enterprise's wealth. However, their realization is uncertain, so they do not have an operational character and should not be associated with the evaluation of performance. However, they do represent future benefits (losses) and should be included in determining the firm's value. 
By adding these last two types of events to the net income, one reaches a broader concept of income, including in its determination all the possible sources of changes in the owners' wealth known to that moment. ${ }^{1}$

Since from a standpoint of economic theory, the change in equity during the period should also be considered as income, the final concept of "comprehensive income" is reached, defined variously as follows:

a) "The change in a business entity's net assets for a period from all sources except transactions with owners" (ROBINSON, 1991);

b) "The change in equity of a business enterprise during a period from transactions and other events and circumstances from nonowner sources. It includes all changes in equity during the period except those resulting from investments by owners and distributions to owners." (SFAC 6, § 70);

c) "The total variation in equity, recognized by the record of transactions or by the revaluation of the company during a determined period, except dividend payments and capital increase or decrease transactions." (HENDRIKSEN; VAN BREDA, 1999).

The usefulness of the comprehensive income concept is linked to its function in guiding investment policies and estimating future cash flows. This is accepted in theory and corroborated by the position of professionals, such as the statement by the Association for Investment Management and Research (AIMR), an entity made up of American market analysts, which in a 1993 document $^{2}$ proposed the publication of broader concepts of income to enable better valuation of companies in the capital market.

There are various ways of reporting the diverse levels of income in accounting. The main question to be addressed here regards how to articulate the income measured and its registration in net worth, i.e., how to demonstrate the variation in the company's value in a given period in function of its income, reported or not.

In this fashion, the clean surplus relation can be defined (LO; LYS, 1999) by the following equation:

$$
\begin{aligned}
& N W_{t}=N W_{t}-N W_{t-1}+I_{t}+D_{t} \\
& N W_{t}=\text { Net worth at the end of the period } \\
& N W_{t-1}=\text { Net worth at the start of the period } \\
& I_{t}=\text { Income measured on the income statement in the period and transferred to } \\
& \text { net worth } \\
& D_{t}=\text { Dividends paid and owners' investments/divestments in the period }
\end{aligned}
$$

This means that only the changes not related to the owners occurring in the net worth in a determined period that have passed through the income statement characterize a "clean" relation between the balance sheet and income statement.

This means to say, in this case, that the accounting system is using the concept of comprehensive income, including all the transactions - recognized in the accounts by the current accounting regime - that have changed the net worth of the company's assets.

Note that the practice of registering some revaluations or assets/liabilities and/or accounting adjustments directly in equity, bypassing the income statement, implies that the

\footnotetext{
${ }^{1}$ The literature has universalized the expression all inclusive to refer to this concept of income. The expression for the aggregate thus calculated is comprehensive income.

${ }^{2}$ Financial Reporting in the 1990's and Beyond, cited in JOHNSON et al. (1995).
} 
increase in the net worth is "contaminated"3 by unreported movements, not properly displayed in the reports of revenue and expense flows.

The statements of changes in equity, in turn, do not provide conceptual clarifications. They only explain the variation between the starting and ending balances of the various equity accounts.

To sum up, the information content of the reports of the changes in net worth of a company's assets (asset/liability approach to measure income), and that highlight the facts generating those changes (revenue/expense approach to measuring income), whether by deliberate actions of management, macroeconomic events or fortuitous and uncommon adjustments, should be broad enough to include all the relevant changes, segmenting the information as shown in Figure 1.

To meet all the needs of users of accounting information, however, it should be borne in mind that the increments in net worth should always be recorded in the statement of income, except for those involving the owners.

\subsection{Evidence from Regulation and Display}

In the United States, in 1997 the FASB established, through SFAS 130, standards for reporting and display of comprehensive income, delineating two forms of presentation, besides permitting the display to be in the income statement or statement of changes in equity.

In essence, the financial statements according to the FASB's standards already detailed current operating income, extraordinary items and the cumulative effects of accounting changes - each of these aggregates net of the respective tax - to arrive at the net after-tax income.

SFAS 130 ordered the addition of "other comprehensive income", referring to "revenues, expenses, gains, and losses that under generally accepted accounting principles are included in comprehensive income but excluded from net income."

These items are specified as: adjustments by foreign exchange conversion/translation; unrealized holding gains and losses on investments in securities (fixed and variable income); and adjustments to the minimum obligation to pension funds sponsored by the company.

This solution was preceded by a great discussion and resulted from changes over time in American accounting principles regarding the way of appraising assets and recognizing revenues.

During the discussions, the American Institute of Certified Public Accountants (AICPA) "endorsed the 'current operating concept' or 'dirty surplus concept'. According to this idea, the net income figure should show only the regular, recurring earnings $[\ldots]$ irregular items $[\ldots]$ should be carried directly to retained earnings (ARB 43)." (KEATING, 1999).

The American Accounting Association was favorable to the concepts of "clean surplus of equity" or "all inclusive income statement," arguing that any gain or loss connected to the company would contribute to its long-term profitability, and thus should be recognized and displayed (KEATING, 1999).

Another technical discussion emerged in the 1990s, raised by Robinson (1991), who argued for the "asset/liability" approach to measuring income, which would imply changes in the accounting standards on valuation of equity items, moving from historic cost to current cost and fair value, entailing a broader approach to determining income.

In this respect, the FASB issued various statements - according to Keating (1999): SFAS 52; SFAS 87; SFAS 107; SFAS 115; SFAS 199 - stratifying the American accounting

\footnotetext{
${ }^{3}$ In this case a dirty surplus accounting flow is constituted in the designation of O'HANLON; POPE (1999). BBR, Braz. Bus. Rev. (Engl. ed., Online), 
regime in the sense of ascertaining income considering the changes in equity, besides the cash flows and profits from companies' recurring activities. But as can be seen from SFAS 130, other items were not contemplated in the report of comprehensive income, continuing to be accounted for directly in accrued earnings.

In the United Kingdom, in 1992 the ASB published FRS 3, entitled Reporting Financial Performance, which gave birth to the Statement of Total Recognised Gains and Losses, analogous to the American concept of comprehensive income.

With the issuance of this standard, the English accounting regime basically eliminated the following items from "dirty" accruals: goodwill acquired; revaluation of assets; exchange rate conversion/translation; and extraordinary items (O'HANLON; POPE, 1999).

In contrast, the IASC has not made a specific statement about the way of displaying income statements, particularly because of its supranational nature. However, it can be seen from the content of its International Accounting Standards (IAS) that its recommendations are in the sense of adopting the concept of comprehensive income, since it generally suggests recording under "Gains \& Losses" all the valuations based on the asset/liability approach to measuring income (revaluation, fair value, goodwill acquired, adjustments in exchange rate translations and in actuarial operations, among others).

This can be seen in the recommendations contained in IAS 8; IAS 19; IAS 21; IAS 32; IAS 36; IAS 39, some already in force and others for application in this and future years. The movement appears to be toward convergence of international accounting standards with their American and English counterparts.

\subsection{Evidence and Models with Comprehensive Income}

Dhaliwal et al. (1999), using information on all American firms contained in the COMPUSTAT and CRSP databases for 1994 and 1995, calculated the proportion of "reported net income" and "direct adjustments to equity" for each company to attain the concept of comprehensive income referring to those years, and then transformed this information linearly in relation to the market value of each company at the start of each period analyzed, obtaining the measurements shown in Table 1.

\begin{tabular}{lrr}
\multicolumn{3}{c}{ Table 1 - Concept of Income in American Companies } \\
1994-1995 & \\
\hline \multicolumn{1}{c}{ Variable } & Mean & $\begin{array}{c}\text { Standard Deviation } \\
(\%)\end{array}$ \\
Net Income & 0.9 & 20.4 \\
Comprehensive Income & 0.7 & 21.7 \\
Comprehensive Income -130* & 1.1 & 20.9 \\
\hline \multicolumn{4}{c}{$*$ Considering only the items included in SFAS 130. }
\end{tabular}

An analysis of Table 1 shows that SFAS 130 did not manage to encompass all the net assets of American companies in the comprehensive income statement, because there is a difference of 0.4 (nearly $40 \%$ of net income) still in the form of dirty surplus, i.e., accounted directly in accrued earnings.

In the same study, the authors used these measurements to test the association between them and the returns on equity of the companies studied, reaching the following conclusions:

a) There is no clear evidence that comprehensive income is, on average, more strongly associated with return on equity;

b) Besides this, comprehensive income is less associated with the market value of the companies; 
c) It is a worse estimator of future cash flows and income than is net income;

d) The only component of "other comprehensive income" that improves the earningsreturn relation is marketable securities adjustment to the market, restricted to the financial sector.

The implication of these results, according to the authors, is that there is no empirical support for requests to measure income on a comprehensive basis and that the only relevant adjustment made by SFAS 130 is that referring to financial assets.

Skinner (1999), evaluating that study, did not consider the results surprising or interesting, given that the authors did not give an economic explanation for the differences between the concepts. Hence, there is no way to expect either of the two concepts to be related to the market returns.

For this author, investors' interest is focused on those components of income that persist in the future. Skinner (1999) also affirms that SFAS 130 only concerns displaying information in another manner and this is no reason for investors' expectations to change.

O'Hanlon and Pope (1999) replicated this study for the English capital market, using data for the 1973-1992 period (the latter year when FRS 3 was implemented), covering all companies whose data were available in the various databases in the United Kingdom. The measurements found are shown in Table 2, namely the net income and dirty surplus, as a proportion of the companies' market value.

Table 2 - Concept of Income in English Companies 1973-1992

\begin{tabular}{lrr}
\hline \multicolumn{1}{c}{ Accrual Period } & & irty Surplus \\
(as \% accrued in the period) & & \\
1 year & 0.117 & -0.005 \\
2 years & 0.263 & -0.006 \\
5 years & 0.762 & -0.046 \\
10 years & 2.417 & -0.261 \\
20 years & 12.346 & -3.418 \\
\hline
\end{tabular}

The components of dirty surplus have positive and negative signs.

The evidence from that study, associating the market return and the income flows not reported in net income in long intervals, are presented by the authors in the following form:

a) The net income reported according to British accounting principles, with direct adjustments to accrued earnings, are relevant to the companies'value;

b) Besides this - and just for tests over long intervals - only the extraordinary items are relevant to the market value;

c) There is little evidence of an association between the market value and other dirty surplus flows in the study.

Therefore, the authors conclude that although it cannot be denied that the items of the type analyzed in measuring income offer opportunities to enrich information regarding income, the evidence from the study does not support this form of presentation, because the inclusion of the items in income does not improve the association between accounting income and return on equity.

Recalling that the evidence demonstrated in these studies did not come from periods when the presentation of comprehensive income was in effect and considering that the effect on investors' decisions can be associated with the format of presenting information rather than the information itself, we now analyze the study in a psychology-based framework conducted by Maines and McDaniel (2000).

In this study, the authors conducted an experiment with nonprofessional investors, using three models containing information about "unrealized gains and losses": in the form of BBR, Braz. Bus. Rev. (Engl. ed., Online), 
clean surplus, as per SFAS 115; in the alternative model of display in the statement of changes in equity, as per SFAS 130; and in the form of the statement of comprehensive income introduced by SFAS 130.

The authors presented their subjects with the situation of an insurance company and analyzed the presentation, evaluation and decision about two sets of circumstances: high and low volatility of the gains on a portfolio of marketable securities.

They found no evidence of differences in perception and evaluation of the situations regarding the three statements. However, the occurrences of high and low volatility were only detected with statistical significance by analyzing the statement of comprehensive income introduced by SFAS 130.

The study also refers to another study, carried out by Hirst and Hopkins (1998) according to Maines and McDaniel (2000) - with professional investors, using data on a manufacturing company. In this study, the investors only managed to perceive the presence of unrealized gains through the comprehensive income statement as per SFAS 130.

The authors conjecture that the difficulty of the professional investors was due to the small investment in securities of nonfinancial companies, concluding that the format of presenting the accounting aggregates affects investors' judgment, although they suggest further study, including comparing other sectors using the same research subjects.

In a more formal manner, in another line of reasoning, the concept of clean surplus was used as a basic assumption in developing company valuation models using accounting information by Ohlson (1995) and further by Feltham/Ohlson (LUNDHOLM, 1995).

These models were derived from the basic assumption that a company's value (net assets) is represented by the present value of future dividends, hence based on the clean surplus relation they stipulate that the firm's current market value will be a function of present value of the stockholders' equity (representing the firm's current cost of capital) plus the present value of abnormal future profits, as in the equation below.

$$
P_{t}=N W_{t}+\sum_{\tau=1}^{\infty} \frac{E_{t}\left(A_{t+}^{a} \tau\right)}{(1+r)}
$$

$P_{t}=$ Equity market value of firm in period $\mathrm{t}$;

$N W_{t}=$ Book value in period t;

$E_{t}=$ Expected value operator on date $\mathrm{t}$;

$A_{t+x}=$ Abnormal Income of period $\mathrm{t}+\mathrm{x}$;

$r_{a}=$ Risk free cost of capital; and

$C I_{t}=C I_{t}-r^{*} N W_{t-1}$, where

$C I_{t}=$ comprehensive income in period $\mathrm{t}$;

$r^{*} N W_{t-1}=$ capital cost of the firm.

The model's articulation, then, depends on the clean surplus relation, because only in this fashion can the dividends and investments be treated correctly, i.e., the subtraction of one unit of money of dividends in the net worth will imply a reduced creation of future profits, and each unit of money added to the company will imply higher future profits, depending on the particular firm's profitability.

The monetary unit obviously does not alter the owners' wealth, except for its future effects, making the market value of the company go down (go up) in identical proportion to the increase (decrease) in other assets of the owners.

However, Lo and Lys (1999), referring to the limitations of the model, presented evidence that the current financial statements do not satisfy the premise discussed above, 
calculating statistics of "dirty adjustments" to equity in the period from 1962 to 1997 of American companies with data available in COMPUSTAT.

These adjustments were calculated by the difference between the comprehensive income and the net income (reported), transformed linearly by the comprehensive income itself, by the net worth and by the total assets.

As can be observed in Table 3, in this period there were significant differences among the American companies between the reported income and the increase in equity. Nearly $25 \%$ of the companies presented adjustments greater than US\$ 1 million in absolute terms.

Table 3 - Difference between Comprehensive Income and Net Income in American Companies 1962-1997

\begin{tabular}{lrrr}
\hline \multicolumn{1}{c}{ Statistics (in \%) } & DS/CI & DS/NW & DS/TA \\
Mean & 15.71 & 3.58 & 1.47 \\
Median & 0.40 & 0.06 & 0.02 \\
\% Cases $>10 \%, 2 \%, 1 \%$, respectively & 14.41 & 11.09 & 9.77 \\
\% of firms with DS > US\$ 1 mm $\rightarrow$ 24.61 & & \\
\hline DS=Dirty Surplus; CI=Comprehensive Income; NW=Net Worth; \\
TA=Total Assets
\end{tabular}

\subsection{Forms of measuring income in Brazil}

Brazilian accounting standards, established in codified law, maintain a rigid structure of presenting results, still based on Law 6404 of 1976 (the basic corporate law), and mirror an also orthodox practice based on the accounting principles established in Federal Accounting Council (CFC) Resolution 750 of 1993, as stated by Capelletto (2004).

The structure of reporting obeys the measurement of income by the revenue/expense approach, demonstrating the concepts of:

a) Operating income for the period, where the revenues and expenses of any type are computed by the revenue realization (transfer of ownership) and accrual regime and linked to the company's operational activities;

b) Non-operating income, basically gains and losses from disposal of assets, along with abnormal gains and losses.

Note there is a distinction between the conception of this last item and that of extraordinary items - which has much more of an unexpected connotation, because extraordinary items are deemed uncommon and irregular (HENDRIKSEN; VAN BREDA, 1999) - although they are measured with the same sense (not part of the operating/recurring income).

Other elements of changes in the values of assets and liabilities are accounted for directly in accrued earnings, as revaluation of assets, permitted by the legislation. Adjustments from past years also pass through net worth, whether caused by changes in accounting forms and practices or errors attributed to past years.

Nevertheless, it must be mentioned that adjustments resulting from ongoing provisions and estimates will always pass through the income accounts, because they depend on supervenience or subsistence only detected in the current period.

Other fundamental differences with international practices in Brazilian legislation are:

a) The Results of Future Years group, which in the view of Iudícibus (2004) is an aberration, because if they do not constitute obligations, they should be appropriated to the results or taken to accrued earnings, or they would be advances on future facts, and hence not recognizable; 
b) The capitalization or deferral of expenses, a practice not always permitted in other jurisdictions, for some items like spending on research and development and publicity costs, among others.

More recently, the Brazilian Central Bank, through its BACEN Circulars 3068 of 2001 and 3082 of 2002; the Superintendent Office of Private Insurance, through SUSEP Circular 192 of 2002; and the Brazilian Securities Commission (Comissão de Valores Mobiliários), through CVM Deliberation 371 of 2000, have taken an asset/liability posture in measurement of income, instituting standards of appraising equity based on the fair market value of assets and liabilities, for the entities under their respective jurisdictions (banking, insurance and listed corporations).

These changes have enriched the display of accounting figures in Brazil, although they are restricted to those sectors.

In the financial and insurance sector, trading and available-for-sale securities ${ }^{4}$ held by financial institutions and insurers, since the second half of 2002, have had to be marked to the market ${ }^{5}$, with their results reflected in operating income for the first group of securities, and booked directly in accrued earnings for the second group.

Starting in 2001, publicly traded corporations in Brazil were required to recognize their obligations to company-sponsored retirement and pension plans, adjusting the amount of contribution paid to by the company to the respective plan to each employee's period of service, in line with the accrual regime, with the resulting adjustments accounted for against the income for the year.

It can be seen, then, that in Brazil the display of income in the income statement is not based on any of the concepts diagramed in Figure 1 - "current operating income", "current income", "net income" or "comprehensive income".

In the first case, this is because the income will not be recurring; in the second concept, because it does not only itemize uncommon or irregular items; in the third aggregate, because it does not account against income the adjustments from prior periods; and in the last case, because it recognizes various changes in the net worth of assets in "dirty" form directly in net worth.

\section{METHODOLOGY}

We now empirically evaluate the dimension of the differences between reported income and comprehensive income in the reality of Brazilian companies. We analyze the relation between the income reported in the income statement and the comprehensive income calculated by the net worth values for Brazilian financial conglomerates, for the period from 2001 to 2004.

The choice of this sector is due firstly to the relevance of the amounts appropriated directly to the companies' equity, because if the issuance of the referred Circulars 3068/01 and $3082 / 02$, and secondly because of the availability of data directly from the Central Bank.

The Central Bank, through BACEN Circular 2990/00 (of June 2000) and BACEN Circular Letter 2940/00 (of September 2000), ordered financial institutions to send quarterly data. Here we examine such quarterly reportings, starting with the second quarter of 2001 until the third quarter of 2004 (period with available data), covering all financial

\footnotetext{
${ }^{4}$ The definition and classification of the assets in these groups, as well as the detailed form of their accounting, can be found in RAMBO; LOUSTEAU (2003).

${ }^{5}$ A method for valuing financial assets in which their value is measured by the present value of their expected cash flows, discounted by the market interest rate in effect at the time of appraisal.

BBR, Braz. Bus. Rev. (Engl. ed., Online),
}

Vitória, v. 4, n. 2, Art. 3, p. 114-131, may.-aug. 2007

www.bbronline.com.br 
conglomerates, therefore excluding isolated financial institutions (not part of conglomerates) and the nonfinancial companies that belong to financial conglomerates

The data were supplied for the study - in previously stipulated spreadsheets - by the Division of Enrollment, Accounting and Financial Information, part of the Central Bank's Financial System Information Department. This information, individualized for each conglomerate, is available from the Bank's site, under "Sistema Financeiro Nacional Informações Cadastrais e Contábeis - Informações Financeiras Trimestrais" (BACEN, 2005).

The accounting aggregates considered were taken from the balance sheet (net worth and adjustments to marketable securities ${ }^{6}$ ), the income statement (net income and interest on stockholders' equity ${ }^{i}$ ) and the statement of changes in financial position (data on capital movements: dividends, share buybacks and pay-ins).

From these data we calculated the comprehensive income (CI), total change in net worth resulting from owners, or to the net income (dirty surplus, or DS), separating from this the effects of adjustments to marketable securities (MS) and other dirty surplus adjustments (ODS), through the equations below.

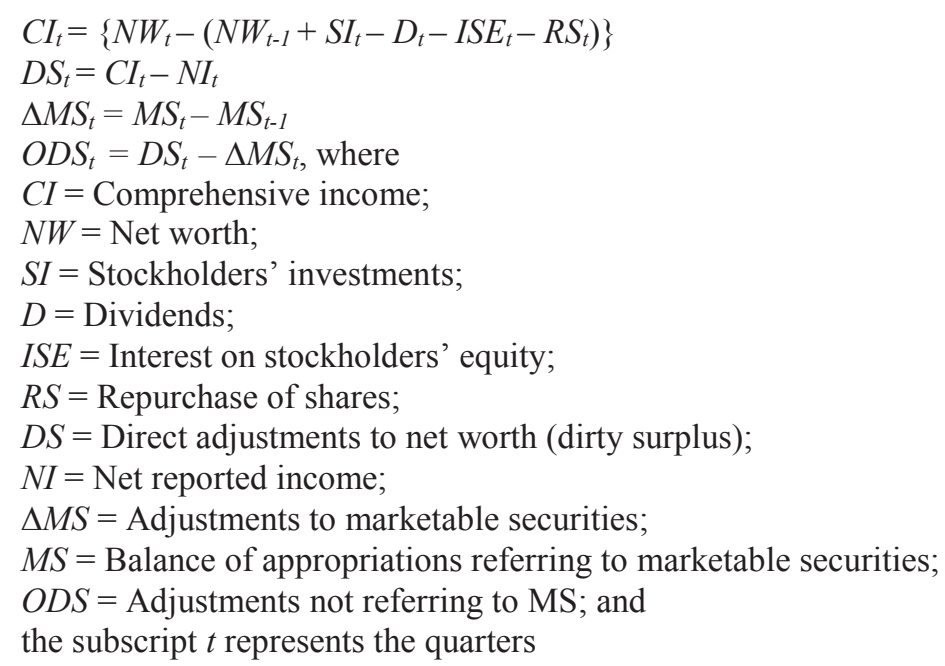

We then performed a linear transformation of these variables, ranked by the final balance of the net worth and the amount of comprehensive income in the quarter.

The sample covering all the financial conglomerates presents the characteristics of Table 4 below, representing a total of 1355 quarterly observations, after removing some outliers that can be attributed to either errors in basic information or irregular behaviors of a particular conglomerate.

\footnotetext{
${ }^{6}$ An account created to receive movements of unrealized gains and losses on available-for-sale securities. 7 Brazilian law allows companies to pay dividends under the title of interest on stockholders' equity, making it tax deductible to the company (but taxable as interest income to the stockholders).
} 


\begin{tabular}{lccccccc}
\multicolumn{8}{c}{ Table 4-Composition of the Sample } \\
Pinancial Conglomerates* \\
Period & \multicolumn{10}{c}{ CU } & $2002 / \mathrm{Q}$ & $2002 / \mathrm{Q}$ & $2002 / \mathrm{Q}$ & $2002 / \mathrm{Q}$ & $2004 / \mathrm{Q}$ & $2004 / \mathrm{Q}$ \\
& 1 & 1 & 2 & 3 & 4 & 1 & 3 \\
\hline Number & 95 & 96 & 97 & 99 & 101 & 100 & 98
\end{tabular}

* The table shows the quarters in which the number of firms changes.

Below we analyze the data from the perspective of describing and assessing the size of the differences between the amounts reported as "income" by the banks studied and the amounts calculated from the standpoint of "clean surplus", assuming that these differences changed in the periods before and after issuance of the mentioned rules by he Central Bank.

\section{ANALYSIS OF THE RESULTS}

First, in Table 5 we show the frequency of the positive and negative adjustments (DS) compared with the frequency of profits and losses reported, as well as the repercussion in terms of frequency on the comprehensive income calculated.

As can be seen, nearly $80 \%$ of the observations had a positive comprehensive income/net worth ratio, while the ratio between adjustments to equity (dirty surplus) and net worth were only positive in $61 \%$ of the cases, leading to the conclusion that comprehensive income would have been less, on average, than the reported income.

In $28 \%$ of the cases there was a negative ratio between dirty surplus and comprehensive income, and in $6 \%$ of the cases there was a change of sign between the reported net income and comprehensive income.

Finally, it is worth noting that in nearly $11 \%$ of the cases there was no dirty surplus, with all the income having been appropriated through the income statement.

Table 5

\begin{tabular}{l|l|l|l|l|l|l}
\hline \multicolumn{7}{c}{ Frequency of positive and negative values } \\
\hline \multicolumn{1}{c|}{ Variables } & \multicolumn{1}{c}{ Positive } & \% of total & Negative & $\%$ of total & Nil & $\%$ of total \\
\hline CI/NW & 1093 & $80.7 \%$ & 251 & $18.5 \%$ & 11 & $0.8 \%$ \\
\hline DS/NW & 830 & $61.3 \%$ & 381 & $28.1 \%$ & 144 & $10.6 \%$ \\
\hline ODS/NW & 866 & $63.9 \%$ & 341 & $25.2 \%$ & 148 & $10.9 \%$ \\
\hline NI/NW & 1077 & $79.5 \%$ & 264 & $19.5 \%$ & 14 & $1.0 \%$ \\
\hline DS/CI & 838 & $61.8 \%$ & 382 & $28.2 \%$ & 135 & $10.0 \%$ \\
\hline NI/CI & 1260 & $93.0 \%$ & 82 & $6.1 \%$ & 13 & $1.0 \%$ \\
\hline
\end{tabular}

The results shown in Tables 6 and 7 allow the following inferences:

a) There are no large differences between the means and medians of the income concepts, but this difference is significant regarding dirty surplus, which means that these adjustments occur with varied signs that offset each other in the set of conglomerates;

b) This assertion is corroborated by the higher proportional standard deviation of the dirty surplus items, since this measure is nearly 20 times the mean found;

c) The dirty surpluses have predominance in appropriating revenues, because the quartiles and maximums of comprehensive income are consistently larger than those of net reported income;

d) This affirmation only does not hold in 2002, where the net income is much larger than the comprehensive income, very likely due to the effect of the first direct appropriation to net worth because of BACEN Circulars 3068/00 and 3082/00, in an environment of rising interest rates; 
Table 6

Descriptive Statistics

Variables Transformed by Net worth

Quarterly Percentages

\begin{tabular}{l|c|c|c|c}
\hline Variables & $\begin{array}{c}\text { Comprehensive } \\
\text { Income } \\
(\mathrm{CI})\end{array}$ & $\begin{array}{c}\text { Dirty Surplus } \\
(\mathrm{DS})\end{array}$ & $\begin{array}{c}\text { Other Adjustments } \\
(\mathrm{ODS})\end{array}$ & $\begin{array}{c}\text { Net Income } \\
(\mathrm{NI})\end{array}$ \\
\hline Minimum Value & $-296.08 \%$ & $-300.31 \%$ & $-299.27 \%$ & $-296.20 \%$ \\
\hline $1^{\text {st }}$ Quartile & $1.35 \%$ & $0.0 \%$ & $0.00 \%$ & $0.90 \%$ \\
\hline Mean & $4.42 \%$ & $0.81 \%$ & $0.78 \%$ & $3.61 \%$ \\
\hline $3^{\text {rd }}$ Quartile & $7.97 \%$ & $1.69 \%$ & $1.60 \%$ & $6.36 \%$ \\
\hline Maximum Value & $221.55 \%$ & $117.62 \%$ & $117.62 \%$ & $206.93 \%$ \\
\hline Standard Deviation & $21.15 \%$ & $16.49 \%$ & $16.35 \%$ & $17.58 \%$ \\
\hline Median & $4.32 \%$ & $0.03 \%$ & 0.01 & $3.74 \%$ \\
\hline
\end{tabular}

Source: BACEN-DEFIN-DINFO

e) However, the effects of these adjustments to marketable securities is not relevant in the period, as can be seen by comparing the respective columns (DS and ODS) in Table 6;

f) In 2002, as can be seen in Table 7, is the only one in which the direct appropriation variable (DS) has a negative sign, although over the whole period analyzed there is a growing positive pattern of these appropriations.

Table 7

Annual Averages

Variables Transformed by Net worth

Quarterly Percentages

\begin{tabular}{l|l|l|l|l}
\hline & \multicolumn{1}{|c|}{2001} & 2002 & \multicolumn{1}{|c|}{2003} & 2004 \\
\hline $\begin{array}{l}\text { Comprehensive } \\
\text { Income }\end{array}$ & $3.51 \%$ & $3.75 \%$ & $5.56 \%$ & $4.64 \%$ \\
\hline Dirty Surplus & $0.93 \%$ & $-0.58 \%$ & $1.54 \%$ & $1.59 \%$ \\
\hline Other Adjustments & $0.93 \%$ & $-0.24 \%$ & $1.08 \%$ & $1.64 \%$ \\
\hline Net Income & $2.57 \%$ & $4.32 \%$ & $4.02 \%$ & $3.05 \%$ \\
\hline
\end{tabular}

Source: BACEN-DEFIN-DINFO

Table 8

Composition of Comprehensive Income As a Percentage

\begin{tabular}{l|l|l}
\hline & \multicolumn{1}{|c|}{ Dirty Surplus } & \multicolumn{1}{c}{ Net Income } \\
\hline Overall Mean & $-30.52 \%$ & $130.45 \%$ \\
\hline 2001 Mean & $23.96 \%$ & $76.04 \%$ \\
\hline 2002 Mean & $-130.87 \%$ & $230.61 \%$ \\
\hline 2003 Mean & $5.90 \%$ & $94.10 \%$ \\
\hline Standard Deviation & $2.41 \%$ & $97.59 \%$ \\
\hline Source BACEN-DEFIN-DINFO & $1057.80 \%$ & $1057.81 \%$ \\
\hline
\end{tabular}

Source: BACEN-DEFIN-DINFO

In Table 8 , we directly analyze relations between the proportion of net income and appropriations to net worth regarding the concept of comprehensive income. On average, there is a slight reduction in the proportion of direct appropriation of income to net worth in relation to the appropriation through net income reported.

However, due to the large standard deviation among the observations, it is more legitimate to consider there is a difference of signs among the conglomerates in appropriation of dirty surplus, that is, in booking expenses and revenues directly in net worth, the positive and negative effects canceling each other out. 


\section{CONCLUSIONS}

One of the main inferences of this study is that what is customarily called accounting income is not necessarily the number ascertained and disclosed in the income statement, since some increases/decreases in the value of net assets are not reported in the statement that supposedly measures the company's performance.

Put another way, we did not find in the principles and rules of the Brazilian accounting regimes examined - or even in the proposals for international convergence of accounting standards - a report that specifically articulates and displays the "clean surplus" / "income for the period" relation, represented by the equation below.

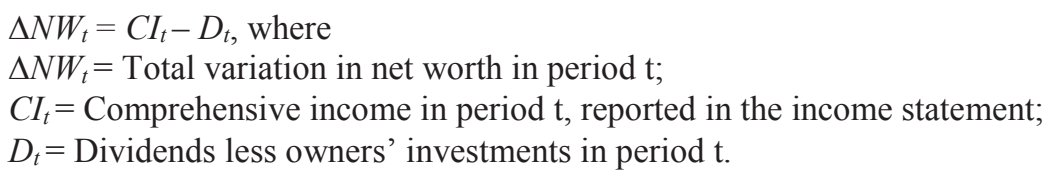

The conflicting structure between the concepts results from two clear trends in the production of accounting information, which are theoretically in counterpoint, namely:

a) A search for approximation of the concepts of economic and accounting income, supported by the approach of measuring income through the changes in assets and liabilities;

b) Maintenance of the concept of clean surplus publication, without contamination from unrealized revenues, expenses, gains and losses.

As was seen in the analysis of the data, there are appreciable differences in the profits reported by the two concepts in the financial statements of Brazilian banks, presenting evidence of large differences in the transition period of the mentioned accounting rules.

The differences between reported net income and clean surplus in the sector, in the period analyzed, are significant, without any reporting of such differences, even in notes to the financial statements.

Further research and studies could be conducted in two directions. The first would entail seeking a more complete taxonomy of the legislation and rules that specify all the events that do not pass through the income statement, but affect the net worth of companies' assets. In this case, special attention could go to measurement of the "results of future years" group.

The other promising path would be to carry out further studies aiming to associate the two concepts of income to companies' returns in the capital market.

\section{REFERENCES}

Banco Central Do Brasil. Circulars 3068 of November 8, 2001 and 3082 of Jaunary 30, 2002. Available at www.bcb.gov.br.

Capelletto, L. R. Nível de Aderência das Demonstrações Contábeis aos Princípios Fundamentais de Contabilidade nos Maiores Bancos Brasileiros. In: Encontro Nacional Da Anpad. Anais do XXVIII ENANPAD; 2004.

Comissão De Valores Mobiliários. Deliberation 371 of 2000. Available at www.cvm.gov.br.

Dhaliwal, Dan; Subramanyam, K. R.; Trezevant, R. Is comprehensive income superior to net income as a measure of firm performance? Journal of Accounting \& Economics, V. 26, pp. 43-67; 1999. 
Edwards. E. O.; Bell, P. W. The Theory and Measurement of Business Income. Los Angeles: University of California Press. 1973.

Fasb. Reporting Comprehensive Income. SFAS No. 130. 1997.

Hendriksen, Eldon S.; Van Breda, Michael F. Teoria da Contabilidade. São Paulo: Ed. Atlas, 1999.

Hicks, J. R. Value and Capital. Oxford: Clarendon Press, 1946.

Iasc. Sumário das Normas Internacionais de Contabilidade. Available at www.iasb.org, Iudícibus, Sérgio de. Teoria da Contabilidade. 6th edition; São Paulo, Ed. Atlas, 2000.

Iudícibus, S. de; Martins, E.; Gelbcke, E. R. Manual de Contabilidade das Sociedades por Ações. 6th edition; São Paulo, Ed. Atlas; 2003.

Johnson, L. T.; Reither, C. L.; Swieringa, J. Toward Reporting Comprehensive Income. Accounting Horizons, Vol. 9, No. 4, pp. 128-137; 1995.

Keating, M. An Analysis of the value of reporting comprehensive income. Journal of Accounting Education, Vol. 17, pp. 333-339; 1999.

Lo, Kin; Lys, T. The Ohlson Model: Contribution to Valuation Theory, Limitations, and Empirical Applications. Journal of Accounting, Auditing \& Finance, pp. 337-367; 1999.

Lundholm, R. J. A Tutorial on Ohlson and Feltham/Ohlson Models: Answers to some frequently asked questions. Contemporary Accounting Research, Vol. 11, No. 2, pp. 749$761 ; 1995$.

Maines, L. A. \& Mcdaniel, L. S. Effects of comprehensive-income characteristics on nonprofessional investors' judgment: The role of financial-statement presentation format. The Accounting Review; Vol. 75, No. 2, pp. 179-207; 2000.

Myers J. N. Implementing residual income valuation with linear information dynamics. The Accounting Review; Vol. 74, No. 1, pp. 1-28; 1999.

Ohlson, J. A. Earnings, book values, and dividends in equity valuation. Contemporary Accounting Research; Vol. 11, No. 2, pp. 661-687; 1995.

O'hanlon, J. F.; Pope, P. F. The Value-Relevance of UK Dirty Surplus Accounting Flows. British Accounting Review, No. 31, pp. 459-482; 1999.

Rambo, R. G.; Lousteau, C. L. Accounting for trading and available-for-sales investments. Journal of Accounting Education, Ed. 21, pp. 127-147; 2003.

Robinson, L. E. The Time has come to report comprehensive income. Accounting Horizons, Vol. 5, No. 2, pp. 107-112; 1991.

Skinner, D. J. How well does net income measure firm performance? A discussion of two studies. Journal of Accounting \& Economics, Vol. 26, pp. 105-111; 1999.

Solomons, David. Economic and Accounting Concepts of Income. The Accounting Review, October; pp. 681-698; 1966.

Superintendência de Seguros Privados. Circular SUSEP-192/02 of June 25, 2002. Available at www.susep.gov.br.U.S. SEC. Study Pursuant to Section 108(d) of the Sarbanes-Oxley Act of 2002 on the Adoption by the United States Financial Reporting System of arinciples-Based Accounting System. Available at www.sec.gov 